ISSN : 0825-8643

\title{
The Costs and Benefits of Reinsurance
}

\author{
J. David CUMMINS \\ Georges DIONNE \\ Robert GAGNÉ \\ Abdelhakim NOUIRA
}

\section{Cahier de recherche $n^{\circ}$ IEA-08-04}

June 2008

Copyright (C) 2008 HEC Montréal.

Tous droits réservés pour tous pays. Toute traduction ou toute reproduction sous quelque forme que ce soit est interdite. Les textes publiés dans la série des Cahiers de recherche HEC n'engagent que la responsabilité de leurs auteurs.

La publication de ce Cahier de recherche a été rendue possible grâce à des subventions d'aide à la publication et à la diffusion de la recherche provenant des fonds de l'École des HEC.

Direction de la recherche, HEC Montréal, 3000, chemin de la Côte-Sainte-Catherine, Montréal (Québec) Canada H3T 2 A7. 


\title{
The Costs and Benefits of Reinsurance*
}

\author{
by \\ J. David Cummins \\ Temple University \\ 1301 Cecil B. Moore Avenue \\ Philadelphia, PA 19122 \\ Phone: (215) 204-8468 \\ Fax: (610) 520-9790 \\ Email: cummins@ temple.edu \\ Georges Dionne \\ HEC Montréal \\ 3000, Chemin de la Côte-Sainte-Catherine \\ Montreal (Qc) \\ Canada H3T 2A7 \\ Phone: (514) 340-6596 \\ Fax: (514) 340-5019 \\ E-mail: georges.dionne@hec.ca. \\ Robert Gagné \\ HEC Montréal \\ 3000, Chemin de la Côte-Sainte-Catherine \\ Montreal (Qc) \\ Canada H3T 2A7 \\ Phone: (514) 340-6435 \\ Fax: (514) 340-6469 \\ E-mail: robert.gagne@hec.ca \\ Abdelhakim Nouira \\ HEC Montréal \\ 3000, Chemin de la Côte-Sainte-Catherine \\ Montreal (Qc) \\ Canada H3T 2A7 \\ Phone: (514) 340-7158 \\ Fax: (514) 340-5019 \\ E-mail: abdelhakim.nouira@hec.ca
}

June 03, 2008

*An earlier version of this article was presented at the SCOR/JRI conference "New Forms of Risk Sharing and Financial Engineering”, Paris, September 2007. 


\begin{abstract}
Purchasing reinsurance reduces insurers' insolvency risk by stabilizing loss experience, increasing capacity, limiting liability on specific risks, and/or protecting against catastrophes. Consequently, reinsurance purchase should reduce capital costs. However, transferring risk to reinsurers is expensive. The cost of reinsurance for an insurer can be much larger than the actuarial price of the risk transferred. In this article, we analyze empirically the costs and the benefits of reinsurance for a sample of U.S. property-liability insurers. The results show that reinsurance purchase increases significantly the insurers' costs but reduces significantly the volatility of the loss ratio. With purchasing reinsurance, insurers accept to pay higher costs of insurance production to reduce their underwriting risk.
\end{abstract}

Keywords: reinsurance, insolvency risk, risk management, financial intermediation, cost functions, panel data. 


\section{The Costs and Benefits of Reinsurance}

\section{Introduction}

Insurers issue policies and collect premiums against the promise of paying claims when accidents occur. For many types of insurance, the gap between the time of the accident and the time of the settlement could reach several years. If an insurer is defaulting during that period, policyholders could lose part of their claims. Therefore, the ultimate interest of any policyholder is the continued financial viability of the insurance company. Policyholders cannot diversify their risk by using many insurers and they do not perfectly monitor the managers of the insurance companies because it is costly and requires a specialized expertise. Furthermore, the potential of large catastrophic losses and the cyclical nature of the insurance business exacerbate the incentives conflict between the different stakeholders (Cummins, Harrington and Klein, 1991; Harrington and Niehaus, 2000; Weiss, 2007). Managing the underwriting residual risks through reinsurance purchase could limit large losses, alleviate the insurance cycle, and reduce agency costs. Hence, reinsurance reduces insolvency risk and strengthens the financial viability of insurance firms.

Most of reinsurance demand studies consider that insurers purchase reinsurance for the same reasons that motivate firms in other industries to purchase insurance or to actively manage their risks: limiting the expected costs of financial distress, stabilizing sources of funding, decreasing expected taxes by exploiting the convex structure of the tax code, and gaining comparative advantages in real services production (Mayers and Smith, 1990; Jean-Baptiste and Santomero, 2000; Cole and McCullough, 2006; Powell and Sommer, 2007; Adams, Hardwick and Zoo, 2008). Maximization of expected utility is another motivation for reinsurance demand (Aase, 2004; and Kaluszka and Okolewski, 2008).

Corporate finance theory suggests that firms purchase insurance to help solve

underinvestment problems. The underinvestment problem occurs when stockholders have 
incentives to forgo an investment with positive net present value because all the benefits from the investment will accrue to debt holders. Mayers and Smith (1987) and Garven and MacMinn (1993) show that firms could guarantee incentive compatibility by including a covenant in the debt contract requiring insurance coverage.

The incentives conflict between stockholders and policyholders is specific to stock insurers. With the mutual ownership structure there is no such incentives conflict because policyholders are themselves the owners. However, mutual insurers purchase reinsurance in the same manner as stock insurers. The mutual ownership structure reduces the access of insurers to the capital market. Therefore, mutuals have traditionally relied on retained earnings as the primary, if not sole, source of capital. Retaining sufficient capital could prevent the need for frequent variations in premiums and dampen the effects of extraordinary periodic underwriting losses but could also create a free cash-flow problem. Wells, Cox and Gaver (1995) find that mutual insurers have a greater level of free cash flow than stock insurers. Thus, mutual insurers purchase reinsurance as an alternative source of capital and to reduce the free cash flow problem.

Transferring risk to reinsurers is expensive. In an examination of the catastrophe reinsurance market, Froot (2001) finds that insurers pay several times the actuarial price of the risk transferred. The high price of reinsurance relative to expected losses could be explained by the combinations of many factors affecting the reinsurance market equilibrium. The shortage of capital in reinsurance and the resulting capacity shortfall drives-up the price of reinsurance, especially following large losses. The agency problems that reinsurers face, due to shareholdermanager incentives conflict and the lack of transparency, increase the costs of reinsurance capital and consequently increase reinsurance prices. Furthermore, it seems that reinsurers' market power has intensified over time with the increase in the capital and market shares of large reinsurers (Cummins and Weiss, 2000b).

In this article, we estimate the effect of reinsurance purchase on the costs and the underwriting risks of U.S. property-liability insurers (554 insurers between 1995 and 2003). 
Firstly, to estimate insurers' cost function we consider ceded premiums to professional reinsurers as an output quality variable. Hence, for a given level of output, an insurer purchasing more reinsurance is considered as producing a higher quality of insurance services. Since purchasing reinsurance is costly, this same insurer will operate with higher costs. We specify a cost function with four outputs (long and short-tail personal, long and short-tail commercial), one output quality variable (reinsurance as measured by ceded premiums), two intermediate output variables (risk management and financial intermediation as defined by Cummins et al. (2007)), six input prices (administrative labour, agent labour, risk labour, material, debt and equity) and yearly dummy variables. Reinsurance, risk management and financial intermediation are treated as endogeneous variables. The results show that reinsurance positively and significantly affects the costs of the insurers in our sample.

Secondly, to estimate the effect of reinsurance purchase on insurers' underwriting risks we consider the growth rate of ceded premiums to non affiliates as a potential determinant of the growth rate of the volatility of the loss ratio. We control for the growth in underwriting risks exposure by including the growth rate of premiums written in each type of business and the growth rate of business concentration and geographic concentration. The results show that purchasing more reinsurance significantly decreases the volatility of loss ratio.

The remainder of the paper is organized as follows. In Section 2, we define the costs and benefits of reinsurance. Section 3 proposes the econometric model and estimation method, while Section 4 presents the data and variables. Section 5 presents and analyses the main results, and Section 6 concludes.

\section{Defining the Costs and Benefits of Reinsurance}

Reinsurance purchase is essentially a capital structure decision. Insurers seek to keep an optimal level of underwriting risk relative to their capitalization level. In the case of large losses, equity holders are only liable to pay losses until the assets of the company have been depleted. If 
there are remaining losses to be paid, equity holders have the option to declare bankruptcy and default in the remaining losses. Phillips, Cummins, and Allen (1998) find that policyholders consider the value of the insolvency option when deciding how much they are willing to pay for the insurance contract. To achieve their solvency target, insurers could increase their capitalization by raising new capital or reduce the risk by transferring a part of it to reinsurers. Thus, reinsurance plays the role of a substitute for capital (Hoerger, Sloan, and Hassan, 1990; and Garven and Lamm Tennant, 2003).

With reinsurance contracts, an insurer transfers premiums collected from customers to a reinsurer. In turn, the reinsurer accepts to bear a part of the risk assumed by the insurer. With proportional reinsurance, premiums and claims are shared between the insurer and the reinsurer in the proportion stipulated in the contractual agreement. In addition, the reinsurer pays a "ceding commission" to the insurer to compensate it for the costs of underwriting the ceded business. However, the commission is also determined by the nature and composition of the insured business and by the underwriting results. In non-proportional reinsurance, the reinsurer assumes only the losses that exceed a certain amount, called the retention or priority. In calculating the price of the risk transferred, the reinsurer takes into account the loss experience during the previous years and the expected future losses according to the type of risks involved.

An insurer will accept to pay loading fees over the actuarial price of the risk transferred. The loading fees should correspond to the cost of the marginal capital needed to support the risk. Since the cost and the quantity of the capital needed to support the risk could be different for the insurer and the reinsurer, the transaction could take place without arbitrage. The reinsurance contract is generally negotiated and signed before the beginning of its effectiveness. At that time, the agreement is accepted by both sides and considered as a fair contract. Moreover, loading fees could include the price of insurer's benefits from reinsurer product development skills and risk management expertise. The reinsurer plays an important role in assessing and underwriting risks, and in assisting insurer's efforts to handle claims efficiently (Swiss Re, 2004). 
An insurer is able to diversify underwriting risk when losses of individual policyholders are statistically independent. In insurance markets where risks are statistically independent, such as automobile collision insurance, the expected losses from a large pool of risks are highly predictable and the loss per claim is moderate. Hence, an insurer will provide coverage for large number of policyholders without having to hold large amounts of costly equity capital relative to the quantity of insurance being underwritten (Doherty and Dionne, 1993).

The problem is that statistical independence is violated when a mega-catastrophe occurs. A single event can cause losses to many policyholders simultaneously. However, the risk of a catastrophe in the U.S. for instance is independent from the risk of a catastrophe in other countries. This provides an economic motivation for a global reinsurance market. The U.S. insurance industry diversifies losses across the world to provide coverage and pay losses in areas such as Florida and California, which have high exposure to catastrophic risks and large concentrations of property values. Thus, with global diversification, the amount of capital needed by international reinsurers to support catastrophic risks is lower than the amount of capital needed by local insurers.

Insurance markets are subject to cycles, experiencing alternating phases of hard and soft markets (Cummins and Outreville, 1987; Cummins, Harrington, and Klein, 1991; Harrington and Niehaus, 2000; Weiss, 2007). In a hard market, the supply of coverage is restricted and prices rise, whereas in a soft market, coverage supply is plentiful and prices decline. Hard markets are usually triggered by capital depletions resulting from large event losses that cause insurers to reevaluate their pricing practices and reassess their exposure management. Following a large loss, it is difficult for insurers to raise capital at a relatively low cost. Thus, insurers have the choice between reducing coverage supply, increasing insolvency risk, and purchasing more reinsurance. Reinsurance allows insurers to maintain client relationships without increasing insolvency risk. However, underwriting cycles characterize both insurers and reinsurers because both of them share the large unexpected losses (Weiss and Chung, 2004; Meier and Outreville, 2006). In soft 
markets, insurers take advantage of low reinsurance prices and high coverage supply by reinsurers to increase their underwriting capacity. In hard markets, when insurers have the largest need for reinsurance, reinsurers' capacity is also reduced and reinsurance prices rise. Actually, this could aggravate insurers' crisis in hard market (Berger, Cummins, and Tennyson, 1992).

In spite of its susceptibility to cycles and crises, the reinsurance market is a global market, and capital markets respond quickly to new capital needs of reinsurers. Following catastrophic losses in 2004-2005, the reinsurance industry raised about $\$ 30$ billion in new capital in a multitude ways: new equity capital for startup companies ( $\$ 9.5$ billion), seasoned equity issues ( $\$ 12.5$ billion), sidecars ( $\$ 5$ billion), and CAT bonds ( $\$ 5$ billion) (Cummins, 2007). Because of this superior capacity to raise quickly new capital, the reinsurance market responded efficiently to large unexpected losses and reinsurance prices began to soften in late 2006 and early 2007 (Benfield, 2007b). Hence, reinsurance alleviates the underwriting cycle and increases the speed of primary insurers to get out of hard market periods.

Even if reinsurance prices exceed the actuarial price of the risk transferred, the reinsurance purchased could remain profitable if the benefits are higher than the costs. Reinsurance reduces insurers' insolvency risk by stabilizing loss experience, increasing capacity, limiting liability on specific risks, and/or protecting against catastrophes. In addition, the purchase of reinsurance reduces incentive conflicts between different stakeholders and consequently reduces agency costs.

\section{Econometric Models and Estimation Methods}

\subsection{Costs analysis}

Most of the existing studies account for the risk pooling and the financial intermediation functions in estimating the cost function of insurers (Cummins and Weiss, 2000a). Cummins et al. (2006) account also for asset-liability management activities. They consider financial intermediation and asset-liability management as intermediate activities performed by the insurer. 
In this paper, we consider the amount of reinsurance purchased as an output attribute variable associated with the level of output produced by an insurer. ${ }^{1}$

We assume that insurance services are produced using a vector of inputs and two intermediate outputs: asset-liability risk management and financial intermediation. For a given level of insurance services, the amount of inputs used by an insurer would be affected by the level of ceded insurance (reinsurance). Presumably, reinsurance is costly and an insurer purchasing more reinsurance will have higher costs for a given level of insurance services. In this framework, reinsurance plays the role of an output attribute or quality variable defining more accurately the output of an insurer. Therefore, we suppose that an insurer is producing insurance services according to the following production function:

$$
Y Q, \operatorname{Re} ; R, F, X^{I}, X^{R}, X^{F}, T=0,
$$

where $Q$ is the quantity of insurance services produced; $R e$ is the quantity of reinsurance purchased; $R$ and $F$ are the intermediate outputs (asset-liability risk management and financial intermediation activities); $X^{I}, X^{R}$ and $X^{F}$ are respectively the quantities of inputs used to produce insurance services, asset-liability risk management, and financial intermediation; and $T$ represents time (for simplicity, we omit the time and firm subscripts).

Under the assumption that insurance firms are cost minimizers and that $Q, R e, R$ and $F$ are pre-determined, the restricted cost function associated with the technology described by (1) is:

$$
C R=C R Q, \operatorname{Re}, R, F, P^{I}, P^{R}, P^{F}, T^{-}
$$

where $C R$ are total costs, and $P^{I}, P^{R}$, and $P^{F}$ are, respectively, the prices of inputs $X^{I}, X^{R}$ and $X^{F}$. The restricted cost function defined by (2) gives the minimum cost of producing the level of insurance services $(Q)$, given the level of reinsurance $(R e)$, asset-liability risk

\footnotetext{
${ }^{1}$ See Dionne, Gagné and Vanasse, 1998 for a discussion on the utilization of output attributes in the context of transportation firms.
} 
management $(R)$ and financial intermediation $(F)$ undertaken by the insurer, the different input prices $\left(P^{I}, P^{R}\right.$, and $\left.P^{F}\right)$, and time $\boldsymbol{C}_{-}$which is included to take into account technical change.

Since the exact functional form of the restricted cost function defined by (2) is unknown, we use the well known translog approximation which is given by:

$$
\begin{aligned}
& \ln C R_{i t}=\alpha_{i}+\sum_{v} \beta_{v}^{Q} \ln Q_{v i t}+\beta^{\mathrm{Re}} \ln \operatorname{Re}_{i t}+\beta_{i}^{R} \ln R_{i t}+\beta_{i}^{F} \ln F_{i t} \\
& +\sum_{s} \beta_{s}^{I} \ln P_{s i t}^{I}+\sum_{j} \beta_{j}^{R} \ln P_{j i t}^{R}+\sum_{k} \beta_{k}^{F} \ln P_{k i t}^{F} \\
& + \text { second-orderterms }+\sum_{t} \beta^{t} D_{t}+u_{i t}
\end{aligned}
$$

where subscripts $i$ and $t$, represent, respectively, firms and time, and $D_{t}$ are time dummy variables (the sample first year being the omitted category). The intercept $\alpha_{i}$ and the coefficients associated with the asset-liability risk management and financial intermediation variables $\left(\beta_{i}^{R}\right.$ and $\left.\beta_{i}^{F}\right)$ are firm-specific. For the estimation, we treat these three parameters as random variables which follow a normal distribution with means $\alpha, \beta^{R}, \beta^{F}$ and variancecovariance $\Omega$. Finally, $u_{i t}$ are i.i.d. random disturbances. Linear homogeneity of degree one in input prices is imposed prior to estimation by dividing total costs and all input prices but one by this last price. Finally, all continuous variables on the right-hand side of (3) are divided by their sample means (the point of approximation).

The reinsurance $(R e)$, asset-liability risk management $(R)$ and financial intermediation $(F)$ variables are likely to be endogenous. Endogeneity is taken into account by first instrumenting these three variables. The set of instruments used includes the log of the insurance output and input prices, time dummy variables and other dummy variables measuring the insurer's characteristics: ownership structure, group membership, distribution system, and head office state. Output and input prices are determined, respectively, on the insurance and labour markets and therefore are properly considered exogenous. Also, ownership structure, group membership, distribution system and head office state are most of the time once and for all decisions 
unaffected by the current situation of the firm (in fact, in our sample, these characteristics are constant over time for almost all firms). It is therefore very unlikely that unobserved variables affecting reinsurance, risk management and financial intermediation would also affect these variables. The predicted values of each endogenous variable are obtained from OLS regressions on the set of instruments and are substituted for the actual values in equation (3). Equation (3) is then estimated by restricted/residual maximum likelihood (REML) as implemented in the Xtmixed procedure of Stata. The proper test statistics of the different estimated parameters of the model are obtained from bootstrapped standard errors with 500 replications.

\subsection{Benefits analysis}

Even though insurers can reduce underwriting risk by diversification, significant residual risk remains, and insurers' claim payments are highly stochastic. Reinsurance is used to reduce insolvency risk by limiting large losses and alleviating the underwriting cycle. Here, we measure the benefits of reinsurance through its effect on the volatility of the loss ratio (the ratio of present value of incurred losses-to-earned premiums). Thus, to assess the consequence of insurers' decision to purchase more or less reinsurance on underwriting risk we estimate the following equation:

$$
\Delta \sigma \boldsymbol{r}_{i t}=\alpha+\beta_{R e} \Delta R e_{i t}+\beta_{X} \Delta X_{i t}+\beta_{Z} Z_{i t}+\beta_{t} D_{t}+e_{i t}
$$

where $\Delta \sigma r_{i}$ is the growth rate of the volatility of loss ratio during the current year, $\Delta \operatorname{Re}_{i t}$ is the growth rate of the reinsurance purchased during the current year, $\Delta X_{i t}$ is a vector of variables measuring the growth rate of insurers' exposure to underwriting risks, $Z_{i t}$ is a vector of insurers' specific control variables, and $D_{t}$ are time dummy variables.

To measure the growth rate in insurers' exposure to underwriting risks, we use the growth rate of premiums written in each type of business, the growth rate of business concentration, the growth rate of geographic concentration, and the growth rate of insurer size. Concentration is 
measured using Herfindahl indices based on net premiums written. As control variables, we use insurers' specific characteristics: ownership structure, group membership, and distribution system. $^{2}$

\section{Data and Variables}

\subsection{Data}

The primary data for our analysis are taken from the regulatory annual statements filed by U.S. property-liability insurers with the National Association of Insurance Commissioners (NAIC). We include data for all property-liability insurance firms reporting to the NAIC for the period 1995 through 2003. However, we eliminate reporting firms showing negative surplus, assets, losses, or expenses. Such firms are not viable operating entities but are retained in the database by the NAIC for regulatory purposes such as the resolution of insolvencies. Because insurers formulate investment and risk management strategies at the overall corporate level, our analysis focuses on groups of insurers under common ownership and unaffiliated single insurance firms. Data for insurance groups are obtained by aggregating the data for affiliated insurance firms which are members of the group. Our analysis focuses on multiple line insurance firms reporting strictly positive output in each of the four lines of insurance business: long-tail personal, short-tail personal, long-tail commercial and short-tail commercial, where the length of the tail refers to the length of the claims payout period for the line of business. Also, insurers reporting non-strictly positive input prices, asset-liability risk, or reinsurance are dropped as well.

Our final samples include 2,966 observations (554 firms). Even though the restriction of strictly positive outputs in all four lines reduces the sample size, most of the firms eliminated are small specialized firms. In fact, our sample accounts for about 90 percent of total industry premium volume in 2003 .

\footnotetext{
2 The Hausman test shows that the growth rate of reinsurance and the growth rate of size are endogenous. Thus, we first instrument these two variables using the same set of instruments as in the first stage of cost function estimation.
} 


\subsection{Costs Analysis}

Most previous studies estimating insurer cost functions consider only the net business assumed, excluding reinsurance quantity from the outputs and reinsurance costs from the total costs. In this paper, since we include reinsurance as an output attribute, we adjust the definition of total costs and the definition of quantities of outputs to reflect those of the total business written and not only outputs and costs associated with the net business assumed.

\subsubsection{Total costs}

The total costs of the net business assumed are generally computed as the sum of total expenses (net of loss adjustment expenses, which are part of the incurred loss outputs) and the cost of capital. To measure total costs related to the total business written we should add the costs of underwriting the ceded premiums to reinsurers. Because direct insurers issue insurance policies and assume all the attached administrative costs, they receive a compensation in the form of commissions from reinsurers when they cede the premiums collected. Thus, the total costs (Costs) of business underwritten is the sum of total expenses, commissions received from the reinsurers, and the cost of capital.

The cost of capital is the sum of the cost of equity capital and the cost of debt capital. ${ }^{3}$ The equity capital (Equity) is defined as the sum of policyholders' surplus and the redundant statutory liabilities (excess of statutory over statement reserves plus provision for reinsurance). The debt capital (Debt), i.e. liabilities, is defined as the sum of losses and loss adjustment expenses reserves, unearned premium reserves, and borrowed money.

\subsubsection{Output quantities and output prices}

The conventional measures of the quantities of outputs for insurers are incurred losses in the four principal property-liability insurance business lines: Long-tail personal, Short-tail personal, Long-tail commercial and Short-tail commercial. The output quantity for a given year is

\footnotetext{
${ }^{3}$ The cost of equity capital is the average quantity of equity capital hold by the insurer during the year multiplied by Equity price. The cost of debt capital is the average quantity of debt capital hold by the insurer during the year multiplied by Debt price. Equity price and debt price are defined below.
} 
usually defined as the present value of incurred losses arising only from the exposure related to the business written during that year. Losses paid during that year but arising from exposures related to the business written during previous years are not included in that year's output quantity. To compute the present value of incurred losses we use the chain ladder parameters and the interest rates term structure obtained for the estimation of liabilities' effective duration. ${ }^{4}$

To be consistent with our approach of accounting for reinsurance, we measure the output associated with the total business written by insurer and not only the output of the net business assumed. Thus, incurred losses associated with the premiums ceded to non affiliated insurers are included in the total output produced by direct insurers.

Output prices are calculated as the difference between premiums earned and the output quantity expressed as a ratio to the output quantity: Output price $e_{\mathrm{ikt}}=\left[\right.$ Premium $\left._{\mathrm{ikt}}-Q_{\mathrm{ikt}}\right] / Q_{\mathrm{ikt}}$, where Premium is premium earned, $Q$ is the output quantity, and subscripts $i, k$, and $t$ refer to insurer $i$, output $k$ and year $t$, respectively. Thus, for each insurer we obtain four different prices: Price of long-tail personal, Price of short-tail personal, Price of long-tail commercial and Price of short-tail commercial.

\subsubsection{Reinsurance}

The quantity of reinsurance purchased is an attribute of the output produced by direct insurers. Everything else being equal, insurers purchasing more reinsurance are assumed to have lower insolvency risk. Reinsurance reduces the insolvency risk of direct insurers by stabilizing their loss experience, limiting their liabilities, and protecting against catastrophes. The most common measure of the quantity of reinsurance purchased is Premiums ceded to nonaffiliates. However, since larger insurers produce more outputs, they can purchase a larger quantity of reinsurance compared to small insurers without ceding a higher proportion of the premiums written. Reinsurance demand studies show that larger insurers cede a lower proportion

\footnotetext{
${ }^{4}$ The chain ladder method is a widely accepted actuarial technique for measuring loss payout patterns. See Taylor (2000).
} 
of premiums written compared to smaller insurers (Mayers and Smith, 1990; and Cole and McCullough, 2006). In our analysis, we also use the share of written premiums that is ceded to non-affiliates insurers (Share ceded to non-affiliates) as an alternative measure of reinsurance.

\subsubsection{Intermediate Outputs}

The first intermediate function we consider is financial intermediation. The insurer receives the premium payments from policyholders at the beginning of the period. When a claim occurs, the insurer pays the amount of the claim at some time in the future. The period between the date of the claim occurrence and the date of the claim payment depends on the type of insurance policy. Financial intermediation activities consist in investing the amount of premiums received until the claim is paid. We measure the quantity of financial intermediation activities by the value of total assets under management, which is equal to invested assets (Invested Assets). This measure of intermediate output has been used in several insurance efficiency studies (Cummins and Weiss, 2000a) and is equivalent to measures used in banks' efficiency studies under the intermediation approach (Berger and Humphrey, 1997).

The second intermediate function is risk management. During the 1995-2003 period, U.S. property-liability insurers invested on average 62 percent in bonds, 14 percent in common stocks, 2 percent in preferred stocks and 20 percent in cash and short-term investments. Thus, the two main risks that affect the value of assets of property-liability insurers are interest rate risk and credit risk. In this study we focus on interest rate risk.

Reducing the insurer's financial risk could create value through, among other things, reducing the market discount in insurance premiums for insolvency risk. As a result, managing the impact of interest rate movements on both assets and liabilities is crucial for insurers (Staking and Babbel, 1995; Santomero and Babbel, 1997). We use the dollar duration of the surplus (Asset-liability Risk) as a proxy for the quantity of output associated with risk management 
activities. ${ }^{5}$ The dollar duration of the surplus is defined as: $S D_{S}=A D_{A}-P V(L) D_{L}$, where $D_{S}$ is the duration of surplus, $D_{A}$ is the duration of assets, $D_{L}$ is the effective duration of liabilities, $A$ is the market value of invested assets, and $P V(L)$ is the present value of liabilities. The surplus of the firm is immunized $\left(D_{S}=0\right)$ when the effect of the interest rate changes on assets is equal to the effect of interest rate changes on liabilities. We do not assume that nil duration of surplus is optimal for insurers. The dollar duration of the surplus is a measure of the quantity of risk that is left after the insurer conducts risk management activities. Rather, we assume that more insurers' risk management activities imply a smaller dollar surplus duration, which contributes to increasing the insurer's value added for the policyholders. ${ }^{6}$

\subsubsection{Variable Inputs}

Insurers use three primary inputs - labour, materials and business services, and capital. In order to better measure the effects of risk management activities, we utilize three labour inputs - administrative labour services, agent labour services, and risk management labour services. Prior insurance efficiency papers have lumped together administrative and risk management labour into a single category. Separating administrative and risk management labour allows us to measure variations in the intensity of risk management across insurers. The other inputs, which are standard in insurance analyses, are materials and business services, debt capital, and equity capital. Administrative labour and materials/business services are shared by insurance, risk management, and financial intermediation activities and, therefore, prices are the same for these activities. Agent labour services are only used for insurance activities. Risk management labour services are used only for the risk management activities. Debt capital and equity capital are inputs needed for financial management and also to support the insurance activities through their impact on insolvency risk.

The price of administrative labour services (Administrative Labour) is the average weekly

\footnotetext{
${ }^{5}$ Surplus is the term used for the book-value of equity capital in the insurance industry.

${ }^{6}$ See Cummins et al. (2006) for details on the computation of the dollar duration of the surplus.
} 
wage in the U.S. state where the head office of the insurer is located for SIC code 6331- Fire, Marine, and Casualty Insurers. The price of agent labour services (Agent Labour) is a weighted average of the average weekly wages in each U.S. state where the insurer operates for SIC code 6411- Insurance agents and brokers. In that case, the weight is the share of premiums written in each state by the insurance firm. The price of risk management input (Risk Labour) is the average weekly wage in each U.S. state where the head office of the insurer is located for the North American Industry Classification System (NAICS) code 52392- Portfolio management. The price of materials/business services (Business Labour) is the average weekly wage also in the U.S. state where the head office is located for SIC code 7300 - Business services. The SIC and NAICS average weekly wages used to compute prices are obtained from the U.S. Bureau of Labor Statistics.

The price associated with debt capital (Debt Price) is defined as the required return by policyholders. This required return is a function of the credit quality of the insurer and the expected waiting time between the occurrence of the accident and the payment of the claim. We compute Debt Price for each insurer as the annualized interest rate equivalent to the rate on the term structure corresponding to the firm's credit quality and with maturity equal to the effective duration of the insurer's liabilities. This produces a different price for each insurer varying by its credit quality and its liability's effective duration. ${ }^{7}$

The price associated with equity capital (Equity Price) is defined as the required return by equity holders. We use the Fama-French three-factor model to estimate the required returns for listed insurers on financial markets. ${ }^{8}$ We assume that listed and unlisted insurers that have the same credit quality also have the same required return on equity. In other words, we categorize insurers by debt quality and take an average within each debt rating of the Fama-French cost of

\footnotetext{
${ }^{7}$ The credit quality term structures are obtained from Bloomberg, and the insurer's credit quality is obtained from Best's Key Rating Guide (A.M. Best Co).

${ }^{8}$ We split listed insurers into three groups based on their A.M. Best's rating. For each year, we estimate the cost of equity capital for each group. The prices of the Fama-French three risk factors were obtained from Kenneth French's website.
} 
capital for the listed insurers.

\subsubsection{Control Variables}

Yearly dummy variables (Year96-Year03) are used to take into account of time. Also, a set of other dummy variables is used to account for insurer characteristics. The Stock ownership dummy is equal to 1 for stock insurers and is equal to 0 otherwise. The Group dummy is equal to 1 if the insurer is an insurance group and is equal to 0 otherwise. The Distribution dummy is equal to 1 if the insurer uses independent agents and is equal to 0 otherwise; and the $\operatorname{State}(s)$ dummy equals 1 if the head office of the insurer is in state $s$. The omitted state is New York.

\subsection{Benefits Analysis}

To assess the benefits of reinsurance purchase we estimate equation (4). The dependent variable in equation (4) is the Growth rate of the volatility of the loss ratio. The loss ratio is defined as the ratio of present value of incurred losses to premiums earned during the same year. It is measured as: $\Delta \sigma r_{i t}=G\left(r_{i t}-\sigma\left(r_{i-1}\right) \sigma r_{i-1}\right.$ where $\sigma(l r)_{i t}$ is the volatility of the loss ratio including current year $\mathrm{t}$ and $\sigma(l r)_{i, t-1}$ is the volatility of the loss ratio excluding current

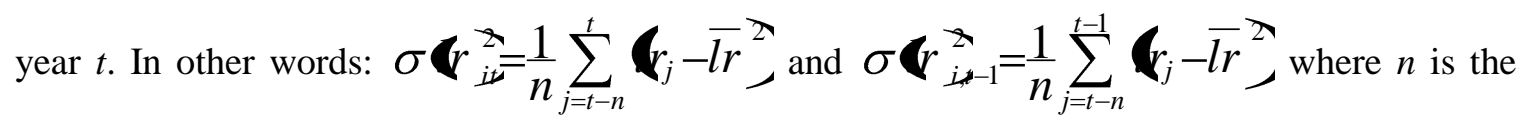
number of historical observations used to calculate the volatility of the loss ratio. We use the historical data reported by insurers in Schedule $\mathrm{P}-$ Part 1 of the NAIC database that go up to the nine previous years. Hence, $\Delta \sigma r_{i}$ is the relative change in the volatility of the loss ratio due only to the underwriting result of the current year.

Our main independent variable to explain the change in the volatility of loss ratio is the Growth rate in the amount of reinsurance purchased measured as $\Delta \operatorname{Re}_{i t}=\left(\mathrm{Re}_{i t}-\mathrm{Re}_{i, t-1}\right\rangle \mathrm{Re}_{i, t-1}$ where $\mathrm{Re}_{i t}$ is defined as the premiums ceded to non affiliates. As with the cost function estimation, as a robustness check, we also use the share of premiums ceded to non affiliates as an 
alternative measure of reinsurance.

To control for the change in insurers' exposure to underwriting risk, we use the growth rate of total premiums written in each type of business (short and long-tail, personal and commercial). In addition, we control for the change in the level of diversification of underwriting activities. For that purpose, we use the Growth rate in line concentration and the Growth rate in geographic concentration. Line concentration is computed as the Herfindahl index of the percentage of premiums in each line of business written by the insurer, and geographic concentration is computed as the Herfindahl index of the percentage of premiums written in each state by the insurer. A higher Herfindahl index implies that the insurer is concentrated in fewer lines of business or in fewer states. Since large insurers are likely to be more diversified, we use also the Growth rate in size. We measure insurers' size as the natural logarithm of total assets.

We control for insurer specific characteristics by including the Stock ownership dummy, Group dummy, and Distribution dummy as defined previously. Finally, we include yearly dummy variables (Year96-Year03) to take into account the effect of time.

\subsection{Summary Statistics}

Summary statistics for all variables used in cost function and reinsurance benefits estimation are presented in Table 1. Insurers ceded on average about $\$ 124$ million/year of premiums to non affiliated reinsurers, representing about 21 percent of total premiums written and assumed from non affiliates during the period 1995-2003. The insurers in the sample produced more personal insurance than commercial insurance, and they produced more long-tail insurance than short-tail insurance. The average amount invested in financial assets is $\$ 1,926$ million, the average return required by policyholders is 6 percent, and the average required return by equity holders is 17 percent.

\section{[Table 1]}

Table 1 also indicates that the average volatility of the loss ratio is 9 percent. The insurance firms are more likely to be organized as insurance groups and more likely to use 
independent agents to sell their policies. The number of stock insurers in the sample is almost equal to the number of mutuals. During the1995-2003 period, insurers increased on average the volume of premiums written in each type of business and the average volatility of the loss ratio increased, at the same time, they increased on average their reinsurance purchases, their business diversification, and their geographical diversification.

\section{Empirical results}

\subsection{Costs Analysis}

Table 2 presents the estimation results for the first stage regressions of the endogenous variables. ${ }^{9}$ The adjusted $\mathrm{R}^{2}$ for Asset-liability risk (0.48), Invested assets (0.50) and Premiums ceded to non affiliates (0.38) are relatively high. Several coefficients associated with the instruments are statistically significant. Some interesting results show up from these regressions. For instance, insurer groups have significantly higher Asset-liability risk, Invested assets, and Premiums ceded to non-affiliates than unaffiliated single insurers. This is consistent with insurance groups being larger and more sophisticated than unaffiliated single insurers. Insurers that use independent agents have lower Asset-liability risk, lower Invested assets, and less Premiums ceded to non-affiliates than direct writer insurers. Thus, insurers that use independent agents are more active in asset-liability management but less active in the reinsurance market than insurers using direct marketing or exclusive agents.

Table 2 also shows that stock insurers purchase significantly more reinsurance than mutual insurers. In the prior literature, empirical results about the effect of organizational form on reinsurance demand are mixed. Mayers and Smith (1990) find that mutual insurers utilize more reinsurance than stock insurers. On the other hand, Garven and Lamm-Tenant (2003) find no significant difference, whereas Cole and McCullough (2006) find that stock insurers purchase more reinsurance than mutuals. These differences in the results may be due to the measure of

\footnotetext{
${ }^{9}$ The Hausman general test shows that reinsurance, asset-liability risk and financial intermediation variables are endogenous in the cost function specification described by equation (3).
} 
reinsurance purchase used or the time period examined. Our empirical results show that stock insurers purchase more reinsurance from non affiliated insurers than do mutual insurers. This finding is expected given the importance of stockholders-policyholders incentives conflicts among stock insurers and the higher involvement of stock insurers in complex lines of business. ${ }^{10}$

\section{[Table 2]}

Table 3 presents the results of the estimation of the cost function as specified in equation (3) with random intercept and random coefficients associated with the risk management and financial intermediation variables. Model 1 is specified with Invested assets and Asset-liability risk but without a reinsurance variable, Model 2 includes a reinsurance variable defined as the quantity of Premiums ceded to non-affiliates, and Model 3 is specified with a reinsurance variable defined as Share ceded to non-affiliates. The inclusion of the reinsurance purchase as a quality variable enhances the cost function specification and allows it to account for the level of underwriting risk being covered by professional reinsurers.

\section{[Table 3]}

The results for Model 1 show that the coefficient for Invested assets is negative and significant at the 1 percent level. A negative coefficient means that the financial intermediation activities decrease the insurance activity costs. The coefficient for Asset-liability risk is positive and also significant at the 1 percent level. Thus, insurers with higher surplus durations or lower risk management have higher insolvency risk and higher insurance costs, primarily due to higher costs of debt and equity capital. The results for financial intermediation and risk management are in line with those found by Cummins et al. (2006).

The results of Model 2 show that the coefficient associated with Premiums ceded to nonaffiliates is positive and significant at the 1 percent level. A positive coefficient means that

\footnotetext{
${ }^{10}$ Head office state dummy variables control the effect of the state insurance regulations. Regulation could limit managerial discretion in investment and risk management decisions. Many of these dummy variables are statistically significant. Results for the 50 head office state dummies are available.
} 
insurers ceding more premiums to non-affiliated insurers have higher insurance costs. This result confirms that reinsurance is costly, as it increases the cost of producing insurance services. Results for Model 2 show that the coefficient associated with Asset-liability risk is positive and statistically significant at the 1 percent level, and the coefficient for Invested assets is negative and statistically significant at the 1 percent level.

The results obtained for Model 3 show that the coefficient associated with the Share ceded to non-affiliates is positive and significant at the 1 percent level. Thus, even after controlling for the quantity of premiums written and assumed, ceding premiums to non affiliated insurers increases the total costs incurred by direct insurers. The results for Invested assets and Asset-liability risk remain significant with the same signs as in Model 1 and Model 2.

\subsection{Benefits Analysis}

Table 4 presents the estimation results for the first stage regressions of the endogenous variables in the volatility of the loss ratio specification described by equation (4). Results from Hausman tests show that endogeneity of the growth rate of insurers' size and the growth rate of reinsurance is not rejected. ${ }^{11}$

\section{[Table 4]}

Table 5 presents the results of the estimation of reinsurance benefits as specified in equation (4). Model 1 is specified with a reinsurance variable defined as the Growth rate of premiums ceded to non-affiliates, and Model 2 is specified with a reinsurance variable defined as the Growth rate of share of premiums ceded to non-affiliates.

\section{[Table 5]}

The results for Model 1 show that the coefficient associated with Growth rate of premiums ceded to non affiliates is negative and statistically significant at the 1 percent level. Thus, ceding more premiums to non affiliated insurers decreases significantly the volatility of the loss ratio. This result confirms that reinsurance purchasing stabilizes loss experience. The results

\footnotetext{
${ }^{11}$ Details regarding the Hausman test results are available from the authors on request.
} 
obtained with Model 1 show also that writing more premiums or increasing the diversification of underwriting activities do not affect significantly the volatility of the loss ratio. However, group insurers and mutual insurers have significantly higher growth rates of loss ratio volatility.

The results obtained for Model 2 show that the coefficient associated with the Growth rate of share of premiums ceded to non affiliates is negative and statistically significant at the 5 percent level. Hence, ceding a larger share of written premiums to non affiliated insurers reduces significantly the volatility of the loss ratio. Results for the other variables are qualitatively the same as those obtained with Model 1 except for the coefficient associated with the growth rate of size which becomes statistically significant. Increasing the size of insurers reduces significantly the growth rate of the volatility of the loss ratio.

\section{Conclusion}

Even though insurers can reduce underwriting risk significantly by diversification and risk management, significant residual risk remains and insurers' claim payments are highly stochastic. One of the most important tools for managing insurance claim risk is reinsurance. Reinsurance reduces insurers' insolvency risk by stabilizing loss experience, increasing capacity, limiting liability on specific risks, and/or protecting against catastrophes. In addition, reinsurance reduces the incentive conflict between the different stakeholders and consequently it reduces agency costs. However, transferring risk to reinsurers is expensive. Reinsurance prices can be several times the actuarial price of the risk transferred (Froot, 2001).

This article estimates the effects of reinsurance on insurers' costs and insurers' underwriting risk by analyzing a sample of U.S. property-liability insurers over the 1995-2003 period. To estimate the effect of reinsurance on insurers' costs, we consider reinsurance as an output attribute of the insurance services produced, and we estimate a parametric cost function. To estimate the effect of reinsurance on insurers' underwriting risk, we consider the growth rate 
of reinsurance purchase as a determinant of the growth rate of the volatility of the loss ratio, controlling for the growth of insurers' exposure to underwriting risk.

The empirical results clearly indicate that reinsurance increases significantly the costs of producing insurance services and reduces significantly the volatility of the loss ratio. These results are robust to the use of alternative reinsurance measures: the quantity of premiums ceded to non affiliates and the share of total premiums that are ceded to non affiliates. Thus, insurers purchasing reinsurance accept to pay higher costs for the production of insurance services to reduce their underwriting risk. 


\section{References}

Aase, K. 2004, Optimal Risk Sharing, in J. Teugels and B. Sundt, eds., Encyclopedia of Actuarial Science, Vol. 3 (Chichester, UK: Wiley).

Adams, M., P. Hardwick, and H. Zou, 2008. Reinsurance and Corporate Taxation in the United Kingdom Life Insurance Industry. Journal of Banking \& Finance, 31(1), 101-115

Benfield, 2007b. Global Reinsurance: 2007 Renewal Roundup-Creme Carmel (London: Benfield)

Berger, L., J. D. Cummins, and S. Tennyson, 1992. Reinsurance and the Liability Insurance Crisis, Journal of Risk and Uncertainty 5(3), 253-272.

Berger, A. N. and D. B. Humphrey, 1997. Efficiency of Financial Institutions: International Survey and Directions for Future Research. European Journal of Operational Research, 98, 175-212.

Cole, C. R. and K.A. McCullough, 2006. A Reexamination of the Corporate Demand for Reinsurance. Journal of Risk and Insurance, 73(1), 169-192

Culp, C. L., 2002, The ART of Risk Management. New York: John Wiley \& Sons.

Cummins, J.D., 2007, Reinsurance for Natural and Man-Made Catastrophes in the United States: Current State of the Market and Regulatory Reforms, Risk Management and Insurance Review, 10(2), 179-220

Cummins, J.D, Dionne, G., Gagné, R., and Nouira, A., 2006. Efficiency of Insurance Firms with Endogenous Risk Management and Financial Intermediation Activities, Working paper 0606, Canada Research Chair in Risk Management, HEC Montreal, 39 pages.

Cummins, J.D., Harrington, S.E., Klein, R.W., 1991. Cycles and Crises in Property-Casualty Insurance: Causes and Implications for Public Policy. Journal of Insurance Regulation, No.Fall, pp.50-93.

Cummins, J.D., Outreville, J.F., 1987. An International Analysis of Underwriting Cycles. Journal of Risk and Insurance, 54(2), pp.246-62.

Cummins, J.D. and Weiss, M.A., 2000a. Analyzing Firm Performance in the Insurance Industry Using Frontier Efficiency Methods, in: G. Dionne, (Ed.), Handbook of Insurance. Kluwer Academic Publishers, Boston, 767-829.

Cummins, J.D. and Weiss, M.A., 2000b. The Global Market for Reinsurance: Consolidation, Capacity, and Efficiency, Brookings-Wharton Papers on Financial Services: 2000, 159222.

Dionne, G., Gagné, R., and Vanasse, C., 1998, Inferring Technological Parameters from Incomplete Panel Data. Journal of Econometric, 87, 303-327.

Doherty, N. and Dionne, G., 1993, Insurance with Undiversifiable Risk: Contract Structure and Organizational Form of Insurance Firms. Journal of Risk and Uncertainty, 6(2), 187-203. 
Froot, K., 2001. The Market for Catastrophe Risk: A Clinical Examination. Journal of Financial Economics, 60(2-3), 529-571.

Garven, J.R., and J. Lamm-Tennant, 2003. The Demand for Reinsurance: Theory and Empirical Tests, Insurance and Risk Management, 71(2), 217-238

Garven, J. R. and R. D. MacMinn, 1993. The Underinvestment Problem, Bond Covenants and Insurance. Journal of Risk and Insurance, 60(4), 635-646.

Harrington, S.E. and G.R. Niehaus, 2000. Volatility and Underwriting Cycles. In: G. Dionne, (Ed.), Handbook of Insurance. Kluwer Academic Publishers, Boston, 657-686.

Hoerger, T. J., F. A. Sloan, and M. Hassan, 1990. Loss Volatility, Bankruptcy, and the Demand for Reinsurance. Journal of Risk and Uncertainty, 3(3), 221-245

Jean-Baptiste, E.L., and A.M. Santomero, 2000. The Design of Private Reinsurance Contracts. Journal of Financial Intermediation, 9(3), 274-297

Kaluszka, M. and A. Okolewski, 2008. An Extension of Arrow's Result on Optimal Reinsurance Contract. Journal of Risk and Insurance, 75(2), 275-288.

Mayers, D., and C. W. Smith, 1990. On the Corporate Demand for Reinsurance: Evidence from the Reinsurance Market, Journal of Business, 63(1), 19-40

Mayers, D., and C. W. Smith, 1987. Corporate Insurance and the Underinvestment Problem. Journal of Risk and Insurance, 54(1), 45-54

Meier, U. and F. Outreville, 2006. Business Cycles in Insurance and Reinsurance: The Case of France, Germany and Switzerland. Journal of Risk Finance, 7(2), 160-176.

Phillips, R. D., J. D. Cummins, and F. Allen, 1998. Financial Pricing of Insurance in the MultipleLine Insurance Company. Journal of Risk and Insurance, 65(4), 597-636

Powell, L.S., and D.W. Sommer, 2007. Internal Versus External Capital Markets in the Insurance Industry: The Role of Reinsurance. Journal of Financial Services Research, 31(2-3), 173189

Santomero, A.M. and D.F. Babbel, 1997. Financial Risk Management by Insurers: An Analysis of the Process. Journal of Risk and Insurance, 64(2), 231-270.

Staking, K.B. and D.F. Babbel, 1995. The Relation Between Capital Structure, Interest Rate Sensitivity, and Market Value in the Property-Liability Insurance Industry. Journal of Risk and Insurance, 62(4), 690-718.

Swiss Re, 2004. Understanding Reinsurance: How Reinsurers Create Value and Manage Risk. Economic Research \& consulting, Swiss Reinsurance Company, Mythenquai 50/60

Taylor, Greg, 2000. Loss Reserving: An Actuarial Perspective. Kluwer Academic Publishers, Boston 
Weiss, M.A., 2007. Underwriting Cycles: A Synthesis and Further Directions. Journal of Insurance Issue, 30(1), 31-45.

Weiss, M.A. and J.H. Chung, 2004. U.S. Reinsurance Prices, Financial Quality, and Global Capacity. Journal of Risk and Insurance, 71(3), 437-467.

Wells, B. P., L. A. Cox, and K. M. Gaver, 1995. Free Cash Flow in the Life Insurance Industry. Journal of Risk and Insurance, 62(1), 50-66. 
TABLE 1

Summary Statistics: 1995-2003

Variable

Mean

Standard Deviation

Premiums ceded to non affiliates

124.15

624.42

448.54

Total premiums ceded

0.21

2485.29

Share ceded to non affiliates

0.32

0.18

Premiums ceded to total premiums

1926.00

Asset-liability risk

18116.37

0.20

Long-tail personal outputs

221.30

99.62

Long-tail commercial outputs

225.94

60.40

6758.46

Short-tail commercial outputs

0.41

73846.93

Price of long-tail personal

0.53

1090.78

Price of short-tail personal

1.30

501.45

731.54

Price of long-tail commercial

0.89

191.40

0.66

0.96

7.66

Price of Short-tail commercial

945.33

2.59

Administrative labour

800.99

170.26

Agent labour

2050.42

150.46

Risk labour

Material/Business labour

609.43

1091.83

Debt Price

0.06

194.60

Equity Price

0.17

0.02

Equity

984.52

0.06

Debt

1310.10

3930.24

Total Costs

499.25

4131.37

Volatility of loss ratio

0.0926

1637.21

Size

19.40

0.0844

323.38

2.11

Long-tail personal premiums

158.18

1541.18

Short-tail personal premiums

351.08

751.04

Long-tail commercial premiums

1158.61

Short-tail commercial premiums

117.93

377.89

Line concentration

0.31

0.15

Geographic concentration

0.49

0.38

Group dummy

0.68

0.47

Stock ownership dummy

0.51

0.50

Distribution dummy

0.67

0.47

Number of observations

Number of firms

554

Note: Quantities of intermediate outputs, quantities of outputs and quantity of reinsurance are in million of real 1995 dollars. Equity, Debt, Total costs, and premiums are in million of current dollars. 
TABLE 2

Results from First Stage Regressions for Cost Function Estimation

\begin{tabular}{|c|c|c|c|c|c|c|}
\hline \multirow[b]{2}{*}{ Variable } & \multicolumn{2}{|c|}{$\underline{\text { Asset-liability risk }}$} & \multicolumn{2}{|c|}{ Invested assets } & \multicolumn{2}{|c|}{$\frac{\text { Ceded premiums to }}{\underline{\text { non affiliates }}}$} \\
\hline & Estimate & t Value & Estimate & t Value & Estimate & t Value \\
\hline Intercept & -3.4016 & -17.23 & -2.7299 & -15.71 & -2.7429 & -15.90 \\
\hline Price of long-tail personal & 0.0506 & 2.78 & 0.0322 & 2.01 & -0.0185 & -1.17 \\
\hline Price of short-tail personal & 0.1052 & 4.94 & 0.1079 & 5.76 & 0.0748 & 4.02 \\
\hline Price of long-tail commercial & 0.0281 & 1.74 & 0.0143 & 1.01 & 0.0188 & 1.34 \\
\hline Price of Short-tail commercial & 0.0883 & 3.93 & 0.0713 & 3.60 & 0.0535 & 2.72 \\
\hline Price of administrative labour & 0.6180 & 0.74 & 0.4953 & 0.68 & 0.4791 & 0.66 \\
\hline Price of agent labour & 0.5672 & 1.33 & 0.9392 & 2.49 & -0.6901 & -1.85 \\
\hline Price of risk labour & -0.3141 & -1.22 & -0.0942 & -0.41 & 0.3772 & 1.67 \\
\hline Price of material/business labour & 0.7130 & 1.40 & 0.9458 & 2.11 & 1.4515 & 3.26 \\
\hline Debt Price & 1.5549 & 3.95 & 2.1048 & 6.07 & 1.0641 & 3.09 \\
\hline Equity Price & -0.6351 & -3.09 & -0.5657 & -3.12 & 0.1125 & 0.63 \\
\hline Distribution dummy & -0.9103 & -12.40 & -0.8152 & -12.61 & -0.3184 & -4.96 \\
\hline Stock ownership dummy & -0.0379 & -0.52 & 0.0987 & 1.54 & 0.3479 & 5.47 \\
\hline Group dummy & 2.6431 & 35.83 & 2.3554 & 36.26 & 1.9487 & 30.22 \\
\hline Number of observations & \multicolumn{2}{|c|}{2966} & \multicolumn{2}{|c|}{2966} & \multicolumn{2}{|c|}{2966} \\
\hline Number of Insurers & \multicolumn{2}{|c|}{554} & \multicolumn{2}{|c|}{554} & \multicolumn{2}{|c|}{554} \\
\hline Adjusted R-sq & \multicolumn{2}{|c|}{0.4868} & \multicolumn{2}{|c|}{0.5054} & \multicolumn{2}{|c|}{0.3820} \\
\hline
\end{tabular}

Note: Results for time dummy variables and state dummy variables are available upon request. Results for alternative measures of reinsurance are not presented but are also available. 


\section{TABLE 3 \\ Cost Function Estimates (Equation 3)}

Model 1: Specified without reinsurance

Model 2: Specified with reinsurance defined as Premiums ceded to non affiliates

Model 3: Specified with reinsurance defined as Share of premiums ceded to non-affiliates

\begin{tabular}{|c|c|c|c|c|c|c|}
\hline & \multicolumn{2}{|c|}{ Model 1} & \multicolumn{2}{|c|}{ Model 2} & \multicolumn{2}{|c|}{$\underline{\text { Model } 3}$} \\
\hline & Estimate & t-ratio & Estimate & t-ratio & Estimate & t-ratio \\
\hline Intercept & 13.3993 & 212.00 & 13.5267 & 182.61 & 13.7071 & 116.20 \\
\hline Financial intermediation & -0.5793 & -4.95 & -0.7538 & -4.81 & -0.5207 & -2.60 \\
\hline Asset-liability risk & 0.7790 & 7.19 & 0.8673 & 6.72 & 0.8549 & 4.16 \\
\hline Reinsurance & & & 0.1696 & 2.75 & 0.3482 & 2.64 \\
\hline Long-tail personal & 0.2338 & 15.04 & 0.2157 & 13.61 & 0.1920 & 9.95 \\
\hline Short-tail personal & 0.0837 & 5.52 & 0.0905 & 5.92 & 0.1024 & 5.76 \\
\hline Long-tail commercial & 0.2586 & 23.32 & 0.2600 & 22.75 & 0.2626 & 18.56 \\
\hline Short-tail commercial & 0.1207 & 8.94 & 0.1309 & 9.47 & 0.1315 & 7.40 \\
\hline Agent labour & 0.4643 & 2.99 & 0.8499 & 4.96 & 1.3033 & 5.13 \\
\hline Risk labour & 0.1466 & 2.99 & 0.1208 & 2.30 & 0.1052 & 1.56 \\
\hline Business labour & 0.0641 & 0.70 & -0.0565 & -0.57 & -0.0207 & -0.16 \\
\hline Debt Price & 0.0945 & 1.24 & 0.1499 & 1.92 & 0.0937 & 1.11 \\
\hline Equity Price & 0.3870 & 10.54 & 0.3285 & 8.22 & 0.3970 & 8.43 \\
\hline Year96 & -0.1055 & -8.62 & -0.0947 & -7.56 & -0.0967 & -7.70 \\
\hline Year97 & -0.0331 & -2.45 & -0.0214 & -1.55 & -0.0320 & -2.36 \\
\hline Year98 & -0.0951 & -4.73 & -0.0688 & -3.21 & -0.0870 & -4.22 \\
\hline Year99 & 0.0018 & 0.08 & -0.0016 & -0.07 & -0.0033 & -0.15 \\
\hline YearOO & -0.0431 & -1.83 & -0.0398 & -1.69 & -0.0449 & -1.91 \\
\hline Year01 & -0.0618 & -1.24 & -0.0355 & -0.71 & -0.0419 & -0.84 \\
\hline YearO2 & 0.0418 & 0.56 & 0.0286 & 0.39 & 0.0435 & 0.59 \\
\hline Year03 & 0.2495 & 2.64 & 0.1983 & 2.11 & 0.2411 & 2.57 \\
\hline Number of observations & 2966 & & 2966 & & 2966 & \\
\hline Number of Insurers & 554 & & 554 & & 554 & \\
\hline -2 Log Likelihood & -189 & & -183.6 & & -183.8 & \\
\hline
\end{tabular}

Results for second-order terms are available from the authors upon request. 
TABLE 4

Results from First Stage Regressions for Volatility of Loss Ratio Estimation

\begin{tabular}{|c|c|c|c|c|}
\hline \multirow[b]{2}{*}{ Variable } & \multicolumn{2}{|c|}{$\underline{\text { size }} \underset{\text { Growth rate of }}{(\log \text { of total assets) }}$} & \multicolumn{2}{|c|}{$\frac{\text { Growth rate of }}{\text { premiums ceded }}$} \\
\hline & Estimate & t Value & Estimate & t Value \\
\hline$\overline{\text { Intercept }}$ & 0.01406 & 2.45 & 6.24959 & 1.65 \\
\hline Price of long-tail personal & 0.00057 & 2.16 & 0.29511 & 1.70 \\
\hline Price of short-tail personal & -0.00010 & -0.56 & -0.05795 & -0.48 \\
\hline Price of long-tail commercial & 0.00002 & 0.89 & 0.00097 & 0.07 \\
\hline Price of Short-tail commercial & 0.00013 & 1.95 & 0.00283 & 0.06 \\
\hline Price of administrative labour & -0.00001 & -2.43 & 0.00056 & 0.20 \\
\hline Price of agent labour & -0.00001 & -2.42 & -0.00376 & -2.13 \\
\hline Price of risk labour & 0.00000 & 3.49 & 0.00018 & 0.57 \\
\hline Price of material/business labour & 0.00000 & 0.94 & 0.00205 & 0.94 \\
\hline Debt Price & 0.06513 & 1.11 & -54.01708 & -1.39 \\
\hline Equity Price & -0.02328 & -3.84 & -4.25408 & -1.06 \\
\hline Distribution dummy & -0.00065 & -1.66 & -0.41769 & -1.61 \\
\hline Stock ownership dummy & 0.00113 & 2.85 & 0.47825 & 1.83 \\
\hline Group dummy & -0.00137 & -3.40 & 0.09660 & 0.36 \\
\hline Number of observations & 2966 & & 296 & \\
\hline Number of Insurers & 554 & & 554 & \\
\hline Adjusted R-sq & 0.043 & & 0.01 & \\
\hline
\end{tabular}

Note: Results for time dummy variables and state dummy variables are available upon request. Results for alternative measures of reinsurance are not presented but are also available. 
Table 5

Volatility of Loss Ratio Estimates (Equation4)

Model 1: Specified with reinsurance defined as Premiums ceded to non affiliates Model 2: Specified with reinsurance defined as Share of premiums ceded to non-affiliates

\begin{tabular}{lcrrrr} 
& \multicolumn{2}{c}{ Model 1 } & \multicolumn{2}{c}{ Model 2 } \\
& Estimate & t-ratio & Estimate & t-ratio \\
\hline Intercept & 0.027180 & 2.10 & 0.033900 & 2.59 \\
Growth rate of reinsurance & -0.013020 & -2.62 & -0.030140 & -1.96 \\
Growth rate of size & -1.989150 & -1.23 & -3.145200 & -2.04 \\
Growth rate of long-tail personal premiums & 0.000006 & 0.35 & 0.000006 & 0.34 \\
Growth rate of short-tail personal premiums & -0.000074 & -0.83 & -0.000066 & -0.73 \\
Growth rate of long-tail commercial premiums & 0.001500 & 1.59 & 0.001470 & 1.56 \\
Growth rate of short-tail commercial premiums & -0.000050 & -0.60 & -0.000051 & -0.62 \\
Growth rate of business concentration & -0.009420 & -0.46 & -0.011200 & -0.55 \\
Growth rate of geographic concentration & -0.011140 & -1.01 & -0.011510 & -1.04 \\
Group dummy & 0.017260 & 2.80 & 0.014470 & 2.34 \\
Stock ownership dummy & -0.016380 & -2.73 & -0.015820 & -2.55 \\
Distribution dummy & -0.000082 & -0.01 & 0.001200 & 0.20 \\
Year96 & 0.063030 & 5.91 & 0.060610 & 5.64 \\
Year97 & -0.011880 & -1.11 & -0.012460 & -1.16 \\
Year98 & 0.008500 & 0.77 & 0.005680 & 0.51 \\
Year99 & 0.016990 & 1.26 & 0.005790 & 0.48 \\
Year00 & 0.018480 & 1.47 & 0.015950 & 1.28 \\
Year01 & 0.025860 & 2.34 & 0.024090 & 2.19 \\
Year02 & 0.009520 & 0.86 & 0.008820 & 0.79 \\
Year03 & 0.027500 & 2.44 & 0.028080 & 2.48 \\
\hline Number of observations & 2966 & & 2966 & \\
Number of Insurers & 554 & & 554 & \\
Adjusted R-sq & 0.0309 & & 0.0299 & \\
\hline
\end{tabular}

